\title{
Use of Senna uniflora as Organic Fertilizer in the Production of Lettuce in the Brazilian Semiarid
}

\author{
Paulo César Ferreira Linhares ${ }^{1}$, Roberto Pequeno de Sousa ${ }^{1}$, Janilson Pinheiro de Assis ${ }^{1}$, \\ Eudes de Almeida Cardoso ${ }^{1}$, Joaquim Odilon Pereira ${ }^{2}$, Walter Rodrigues Martins ${ }^{2}$, \\ Anderson Bruno Anacleto de Andrade ${ }^{1}$, Robson Pequeno de Sousa ${ }^{3}$, Lunara de Sousa Alves ${ }^{1}$, \\ Mateus de Freitas Almeida dos Santos ${ }^{1}$, Lindomario Francisco de Oliveira ${ }^{1}$, \\ Willianny Karem de Sousa ${ }^{4} \&$ Sabrina Queiroz de Freitas ${ }^{4}$ \\ ${ }^{1}$ Jitirana Research Group, Department of Agronomic and Forestry Sciences, Federal Rural Semi-arid University, \\ Mossoró, RN, Brazil \\ ${ }^{2}$ Center of Exact and Natural Sciences, Federal Rural Semi-arid University, Mossoró, RN, Brazil \\ ${ }^{3}$ Computing Department, State University of Paraíba, Campina Grande, PB, Brazil \\ ${ }^{4}$ Federal Rural Semi-arid University, Mossoró, RN, Brazil \\ Correspondence: Paulo César Ferreira Linhares, Jitirana Research Group, Department of Agronomic and Forestry \\ Sciences, Federal Rural Semi-arid University, Mossoró, RN, Brazil. E-mail: paulolinhares@ufersa.edu.br
}

Received: February 4, 2020

Accepted: March 21, $2020 \quad$ Online Published: April 15, 2020

doi:10.5539/jas.v12n5p48

URL: https://doi.org/10.5539/jas.v12n5p48

\begin{abstract}
The use of plant resources available on the farm, and of great relevance to the family farmers of the Northeastern semi-arid region, Brazil. The experiment was carried in the experimental area of the agricultural science center, Universidade Federal Rural do Semi-árido (UFERSA), Mossoró, Brazil, with the objective of evaluating use of Senna uniflora as organic fertilizer in the production of lettuce in the Brazilian semiarid, from October 2014 to February 2015. The experimental design of randomized complete blocks with the treatments arranged in $4 \times 4$ factorial scheme, with three replicates. The first factor consisted of amounts $S$. uniflora $(0,1.8,3.6$, and $5.4 \mathrm{~kg}$ $\mathrm{m}^{-2}$ of dry matter) with four incorporation times into the soil $(0 ; 28 ; 56$ and 84 days before transplanting lettuce). The transplanted lettuce cultivar went was the "Elba". The evaluated characteristics were the following: plant height, diameter plant, number of leaves per plant, green mass production and dry mass production. The best agronomic efficiency was obtained with soil incorporation of $5.4 \mathrm{~kg} \mathrm{~m}^{-2}$ in the incorporation period of 56 days after transplanting, with phytomass production of $235.2 \mathrm{~g} \mathrm{plant}^{-1}$. S. uniflora becomes a viable option to be used as an organic fertilizer in lettuce production.
\end{abstract}

Keywords: spontaneous species, agroecological production, family farming

\section{Introduction}

Soil degradation with chemical fertilization causes a decrease in the productive capacity, altering the structure and its soil fauna, besides provoking an entire erosive process, leading to losses of soil and nutrients Sustainable agriculture is the basis of agroecological production, a system of production without the use of chemical inputs. In the semi-arid region of the Brazilian Northeast, family farmers potentiate their production with the use of animal fertilizers, cattle manure and goat. However, because it is a resource with little availability among farmers, it contributes to increasing production costs (Linhares et al., 2014).

In the semi-arid region, several spontaneous species appear annually in the rainy season. Among the species, Senna uniflora L., legume that occurs in the rainy season, with spontaneous predominance in areas of agricultural cultivation, is considered as an infesting plant, with dry biomass production of $4.0 \mathrm{t} / \mathrm{ha}$ and nitrogen (N) content of $18.5 \mathrm{~g} \mathrm{~kg}^{-1}, 60$ days after the emergency, being harvested and used as organic fertilizer in the production of vegetables (Linhares, 2013).

Among the cultivated vegetables, the lettuce (Lactuca sativa L.) of the family Cichoriaceae stands out, being produced all over Brazil using several cultivars, of which about eighteen are national (Filgueira, 2012). This vegetable has played an increasingly important role in the list of food products for the families, being sold in nature in supermarket and agroecological fairs. 
According to Linhares (2013) the practice of incorporating or leaving the organic residue in cover brings benefits to the soil-plant system. In addition, it guarantees the producer success in the production and optimization of the resources used. The organic fertilization with spontaneous Caatinga species is an alternative for small farmers in the semi-arid region. Aiming an agroecological production, many researchers and farmers seek for sustainable and diversified agricultural systems with low chemical inputs (Altieri, 2012).

The study of plant species of the Brazilian Northeast as an organic fertilizer is of great importance because they are plants that are present in the growing areas. The agronomic efficiency of these species as organic fertilizer has been verified in some crops, as in arugula (Linhares et al., 2009, 2010); lettuce (Linhares et al., 2011a; Góes et al., 2011; Bezerra Neto et al., 2010); carrot (Linhares et al., 2011b); coriander (Linhares et al., 2012, 2013, 2018); cabbage (Linhares et al., 2014) and beet (Linhares et al., 2015).

Given the importance of the use of Northeastern semiarid species as organic fertilizer in the production of vegetables, the following research hypothesis was presented: The yield of lettuce depends on the greater amount and period of incorporation of $S$. uniflora. Therefore, it was aimed, to study organic fertilization with Use of $S$. uniflora as organic fertilizer in the production of lettuce in the Brazilian semiarid.

\section{Material and Methods}

\subsection{Study Area}

The study area was located at the Rafael Fernandes experimental farm, in the period from October 2014 to February 2015, in the district of Alagoinha (5 $\left.5^{\circ} 03^{\prime} 37^{\prime \prime} \mathrm{S}, 37^{\circ} 23^{\prime} 50^{\prime \prime} \mathrm{W}\right)$, northwest of Mossoró, State of Rio Grande do Norte, Brazil, which has approximately 400 hectares (Rêgo et al., 2016). The production system is located in the semi-arid region of Brazil.

\subsection{Characterization of Soil and Climate}

The soil of the experimental area was classified as Eutrophic Red Yellow Argissolo, Caatinga hyperxerophilic phase and flat relief (Embrapa, 2018). According to Kottek et al. (2006) and the classification of Köppen, the local climate is BSwh', dry and very hot, the dry season being normally from June to January, and a rainy season being from February to May. The average annual rainfall is $673.9 \mathrm{~mm}$ and the average relative humidity is $68.9 \%$.

Before the installation of the field experiment, soil samples were collected to a $0-20 \mathrm{~cm}$ layer and then sent to be processed and analyzed in the Universidade Federal Rural do Semi-árido (UFERSA) Water, Soil and Plant Analysis Laboratory, providing the following results: $\mathrm{pH}$ (water 1:2,5) $=6.80$; exchangeable cations $\mathrm{Ca}$ (calcium) $=0.60 \mathrm{cmol}_{\mathrm{c}} \mathrm{dm}^{-3} ; \mathrm{Mg}($ magnesium $)=0.80 \mathrm{cmol}_{\mathrm{c}} \mathrm{dm}^{-3} ; \mathrm{K}($ potassium $)=32.5 \mathrm{mg} / \mathrm{dm}^{3} ; \mathrm{Na}($ sodium $)=9.4$ $\mathrm{mg} / \mathrm{dm}^{3} ; \mathrm{P}$ (phosphorus) $\left(\right.$ Mehlich) $=2.8 \mathrm{mg} \mathrm{dm}^{-3}$; organic matter $(\mathrm{OM})=0.75 \mathrm{~g} / \mathrm{kg}$; coarse sand $=630 \mathrm{~g} / \mathrm{kg}$; fine sand $=270 \mathrm{~g} / \mathrm{kg}$; silte $=20 \mathrm{~g} / \mathrm{kg}$; clay $=70 \mathrm{~g} / \mathrm{kg}$, soil density $=1.42 \mathrm{~g} / \mathrm{cm}^{3}$.

\subsection{Experimental Design and Treatments}

The experimental design of randomized complete blocks with the treatments arranged in $4 \times 4$ factorial scheme, with three replicates. The first factor consisted of different amounts of $S$. uniflora incorporated into the soil ( 0.0 , $1.8,3.6$ and $\left.5.4 \mathrm{~kg} \mathrm{~m}^{-2}\right)$ the second factor to the times of incorporation into the soil $(0.0,28,56$ and 84 days before the transplanting of lettuce).

The propagation of the lettuce seedlings was done in expanded polyethylene trays of 128 cells, containing vermiculite substrate. The seedlings were grown in a greenhouse for 15 days with $50 \%$ shading until they reached about $10 \mathrm{~cm}$ in height. Each plot had a total area of $1.96 \mathrm{~m}^{2}(1.40 \mathrm{~m} \times 1.40 \mathrm{~m})$ containing 49 lettuce plants spaced of $0.20 \mathrm{~m} \times 0.20 \mathrm{~m}$. The harvest area of each plot was $1.0 \mathrm{~m}^{2}(1.00 \mathrm{~m} \times 1.00 \mathrm{~m})$ containing 25 lettuce plants.

\subsection{Nutrient Content of S. uniflora}

S. uniflora was harvested in June 2014, in an area of semi-arid shrub vegetation in the flowering period. Soon after being harvested the material was crushed and dried in the sun, being packed in raffia bags to be used as an organic fertilizer. The material was sent to the soil fertility and nutrition laboratory at the UFERSA Agricultural Sciences Center, with a chemical concentration of $16.5 \mathrm{~g} / \mathrm{kg}$ of N; $870 \mathrm{~g} / \mathrm{kg}$ of OM; $402 \mathrm{~g} / \mathrm{kg}$ of organic carbon (C); 24/1 C/N ratio; $0.68 \mathrm{~g} / \mathrm{kg}$ of P; $5.87 \mathrm{~g} / \mathrm{kg}$ of K; $1.45 \mathrm{~g} / \mathrm{kg}$ of Na; $0.23 \mathrm{~g} / \mathrm{kg}$ of Ca and $0.05 \mathrm{~g} / \mathrm{kg}$ of Mg.

During the period of stay of residues in the soil, prior to planting, irrigations were made in order to maintain soil moisture at $70 \%$ of field capacity, and this is an ideal condition for nitrification (Novais 2007). 


\subsection{Evaluation of the Characteristics Studied}

After harvesting, plants were transported to the Post-Harvest of Vegetables Laboratory at the Department of Agronomic and Forestry Sciences at UFERSA where they were analyzed.

The characteristics evaluated were as follows: plant height (was measured from twenty plants of the useful area, using millimeter rule, being expressed in $\mathrm{cm} / \mathrm{plant}$ ), diameter plant (was estimated through the distance between the opposing edges of the leaf disc, measured with a ruler and expressed in centimeter of twenty plants), number of leaves per plant (was measured with a sample of twenty plants, with result expressed in leaves/plant), green mass production (was obtained by removal all plants of the useful area, weighed in a precision scale of $1.0 \mathrm{~g}$, expressed in $\mathrm{g} / \mathrm{plant}$ ) and dry mass production (measured by determining the dry matter content of lettuce in $\mathrm{g} / \mathrm{kg}$, multiplied by green mass production in $\mathrm{m}^{2}$, expressed in $\mathrm{g} / \mathrm{plant}$ ).

\subsection{Statistics Analysis}

Analyses of variance were conducted for the evaluated characteristics using the ESTAT software (Kronka \& Banzato, 1995). Response curve adjustment for the quantitative factor was performed using the Table Curve software (Systat Software Inc., 2002). The response functions were evaluated based on the following criteria: biological rationale, significance of the mean square of the regression (QMRr), high coefficient of determination $\left(\mathrm{R}^{2}\right)$, significance of the regression parameters, using the $\mathrm{t}$ test at $p<0.01$ probability).

\section{Results and Discussion}

\subsection{Analysis of Variance}

There was interaction between the amounts and periods of incorporation of the S. uniflora in the characteristics of the diameter of the plant and green mass of lettuce. However, there was an isolated effect at the level of probability $(p<0.01)$ in the different amounts of $S$. uniflora for plant height, number of leaves/plant and dry mass. In relation to the incorporation periods, there was a difference in the level of probability $(p<0.01)$ for height and number of leaves per plant and dry mass (Table 1).

Table 1. F values for plant height, expressed in $\mathrm{cm} /$ plant $(\mathrm{BH})$, number of leaves/plant, expressed in units/plant (NL), diameter for plant, expressed in cm (DP), green mass production (GP) and dry mass (DM) of lettuce under different amounts and times of incorporation of Senna uniflora

\begin{tabular}{lllllll}
\hline Causes of variation & $\mathrm{GL}$ & $\mathrm{BH}$ & $\mathrm{NL}$ & $\mathrm{DP}$ & $\mathrm{GP}$ & $\mathrm{DM}$ \\
\hline Amounts (A) & 3 & $10.82^{* *}$ & $9.65^{* *}$ & $11.45^{* *}$ & $11.70^{* *}$ & $13.42^{* *}$ \\
Incorporation (I) & 3 & $8.78^{* *}$ & $10.48^{* *}$ & $7.85^{* *}$ & $13.22^{* *}$ & $8.45^{* *}$ \\
$\mathrm{~A} \times \mathrm{B}$ & 9 & $1.56^{\mathrm{ns}}$ & $0.41^{\mathrm{ns}}$ & $12.5^{* *}$ & $17.2^{* *}$ & $0.8^{\mathrm{ns}}$ \\
Treatments & 15 & - & - & - & - & - \\
Bloks & 2 & $6.50^{*}$ & $5.1^{*}$ & $10.2^{* *}$ & $17.2^{* *}$ & $14.5^{* *}$ \\
Waste & 30 & - & - & - & - & - \\
$\mathrm{CV}(\%)$ & - & 13.7 & 19.4 & 16.8 & 18.3 & 13.5 \\
\hline
\end{tabular}

Note. ${ }^{* *}=\mathrm{P}<0.01$, statistical significance at $1 \%$ probability, ${ }^{*}=\mathrm{P}<0.05$, statistical significance at $5 \%$ probability and ${ }^{\mathrm{ns}}=$ not significant.

\subsection{Plant Eight, Leaves per Plant and Diameter}

There was an increase in height and number of leaves per plant, with the addition of $S$. uniflora, reaching maximum values of $25.02 \mathrm{~cm} /$ plant and 28.8 leaves/plant, in the amount of $3.6 \mathrm{~kg} / \mathrm{m}^{2}$, occurring decrease up to the amount of $5.4 \mathrm{~kg} / \mathrm{m}^{2}$ (Figures 1A and 1B). For the periods of incorporation, 54 days before planting promoted the greatest increase in plant height and leaves, with maximum values of $23.65 \mathrm{~cm} / \mathrm{plant}$ and 31.46 leaves/plant (Figures 2A and 2B). 
(A)

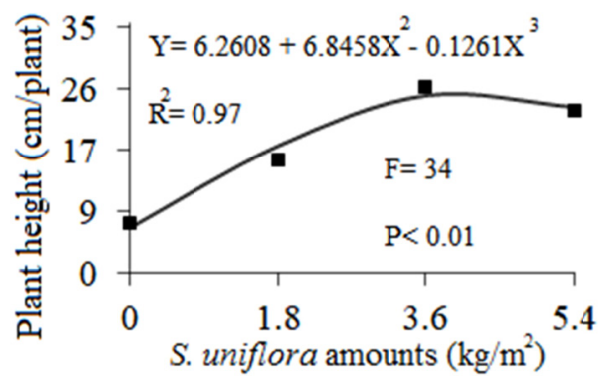

(B)

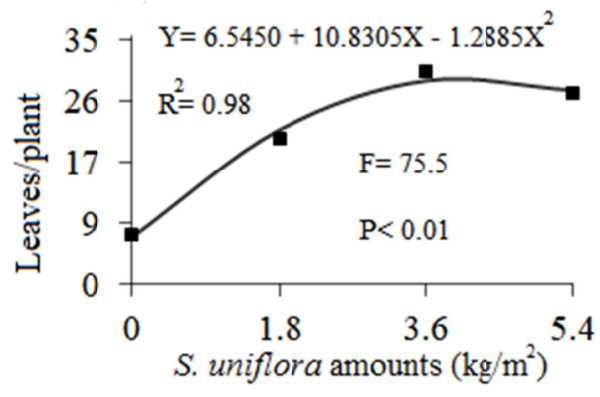

Figure 1. Plant height (A) and leaves/plant of lettuce (B) in function of amounts of S. uniflora incorporation into the soil

\section{(A)}

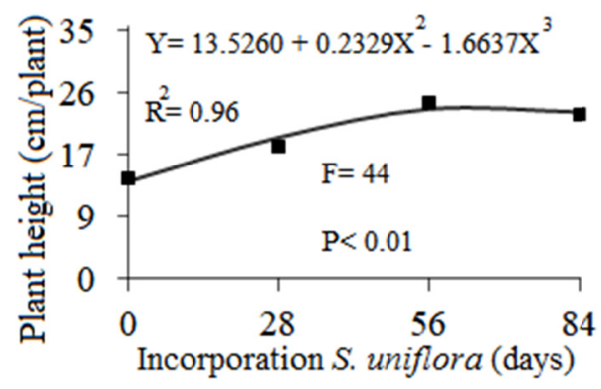

(B)

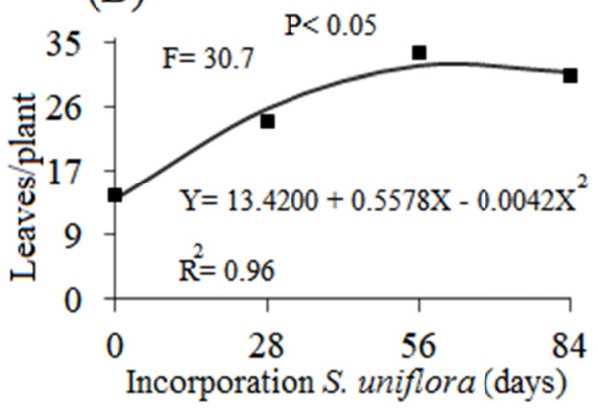

Figure 2. Plant height (A) and leaves/plant of lettuce (B) in function the incorporation periods of S. uniflora

The higher plant height was probably due to higher availability of nitrogen at the time of increased plant demand. The number of leaves is a characteristic of great importance for leafy vegetables, in view of being this organ responsible for photosynthesis, besides being the commercialized part of the vegetable. The higher plant height was probably due to higher availability of nitrogen at the time of increased plant demand. higher value was observed by Góes et al. (2011) studying the productive performance of lettuce at different amounts and times of decomposition of dry scarlet starglory, they found plant height of $25.3 \mathrm{~cm} /$ plant. Oliveira et al. (2009) obtained lower results using organic fertilizers in the culture of the lettuce, obtained an average of 24.6 leaves using organic manure management of mucuna-preta.

Santi et al. (2013) Agronomic performance of crisphead lettuce fertilized with filter cake in protected environment, found an average value of leaves of 27.8 units/plant, being superior to said research.

Partitioning of the amounts of S. uniflora within of the periods of incorporation was observed in the diameter of the lettuce, with values of $19.10 ; 19.02 ; 24.02$ and $22.33 \mathrm{~cm}$, in the amount of $3.6 \mathrm{~kg} / \mathrm{m}^{2}$, corresponding to the incorporation periods of $0 ; 28 ; 56$ and 84 days after sowing (Figures 3A, 3B, 3C and 3D). For the incorporation periods, there was partitioning within the amounts of $S$. uniflora, with values of $16.16,19.80$ and 22.17 in the amounts of 1.8, 3.6 and $5.4 \mathrm{~kg} / \mathrm{m}^{2}$, respectively (Figures 4A, 4B and 4C). 
(A)

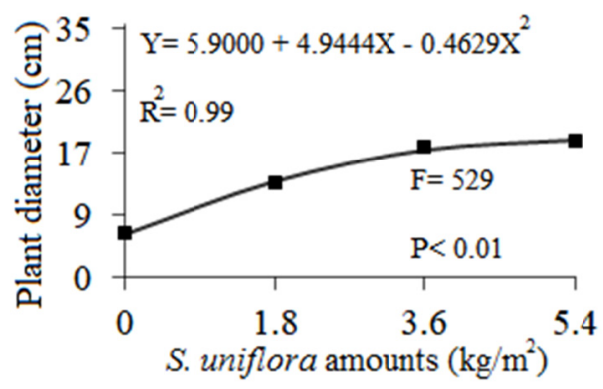

(C)

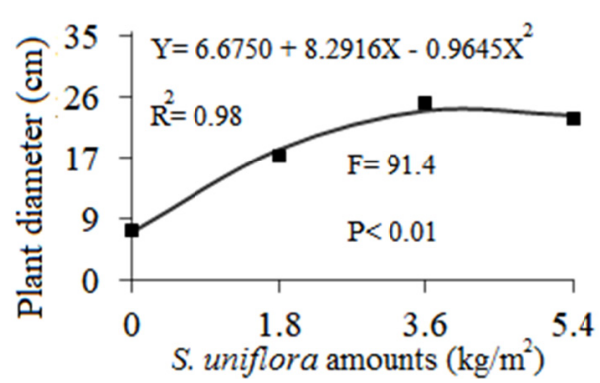

(B)

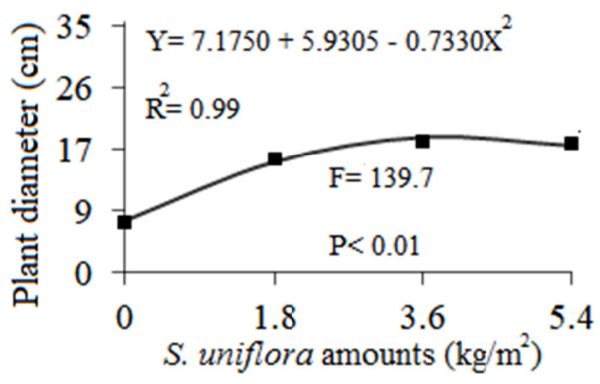

(D)

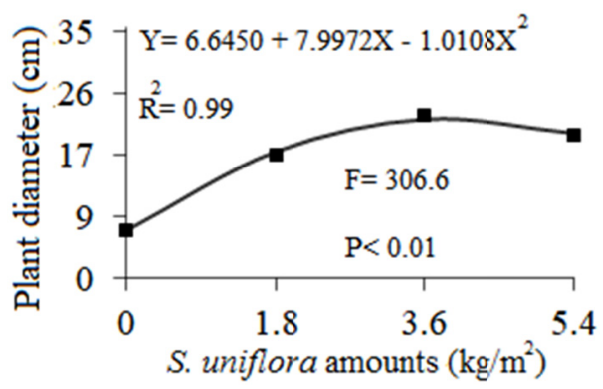

Figure 3. Diameter of lettuce plant, in function of partitionig of the amounts of Senna uniflora within of the periods of 0 day (A), 28 days (B), 56 days (C) and 84 days (D) of incorporation in the soil

(A)

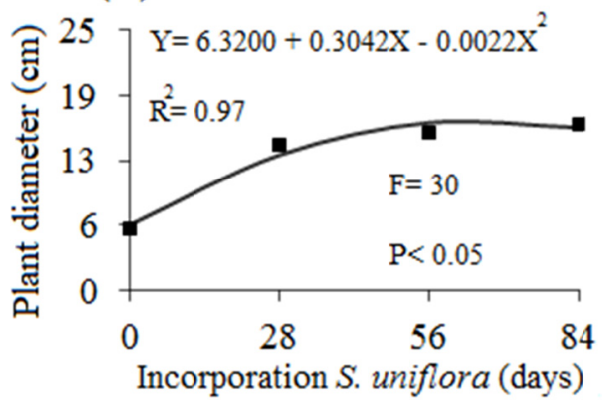

(B)

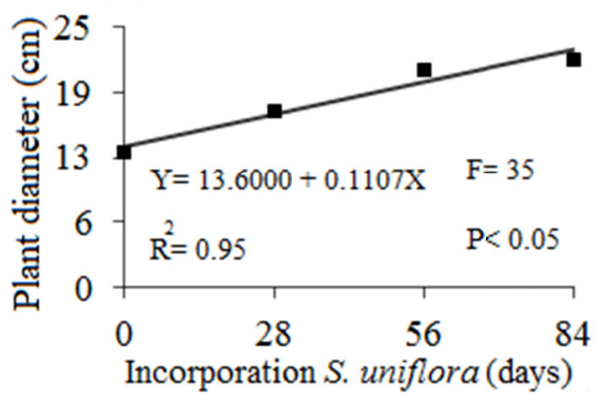

(C)

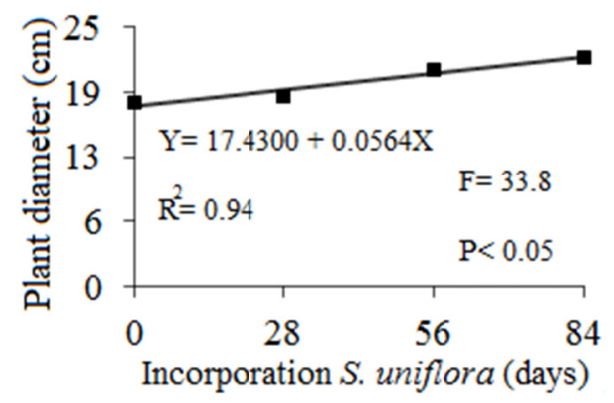

Figure 4. Diameter of lettuce plant, in function of partitionig of the incorporation periods in the amounts of $1.8(\mathrm{~A})$, 3.6 (B) and $5.4 \mathrm{~kg} / \mathrm{m}^{2}$ (C) of Senna uniflora incorporation in the soil

At the agroecological fair in northeastern Brazil, the commercial diameter of commercialized lettuce is between 20 and $25 \mathrm{~cm}$. Santi et al. (2013) evaluating agronomic performance of crisphead lettuce fertilized with filter cake in 
protected environment with plant diameter of $29.5 \mathrm{~cm}$ in tainá cultivar. In a similar study, Linhares (2009), cultivating the lettuce cultivar 'Babá de Verão' between winter and spring in northeastern Brazil, achieved a plant diameter of $22.90 \mathrm{~cm}$, fertilizing with $15.6 \mathrm{t} \mathrm{ha}^{-1}$ of roostertree manure incorporated into the soil 15 days before transplanting.

\subsection{Green Mass Production and Dry Mass}

Increasing linear function and a quadratic function were adjusted for partitioning of the amounts of $S$. uniflora, within the periods of incorporation, with maximum values of 171.0; 203.8; 235.2 and $176.8 \mathrm{~g} / \mathrm{plant}$ in the green mass, for the incorporation periods of $0 ; 28 ; 56$ and 84 days after transplanting, respectively (Figures 5A, 5B, 5C and 5D). Partitioning incorporation periods within of amounts of $S$. uniflora with maximum values of $160 ; 165$ and $192 \mathrm{~g} /$ plant in the green mass, for the amounts of $1.8 ; 3.6$ and $5.4 \mathrm{~kg} / \mathrm{m}^{2}$ (Figures $6 \mathrm{~A}, 6 \mathrm{~B}$ and $6 \mathrm{C}$ ).

(A)

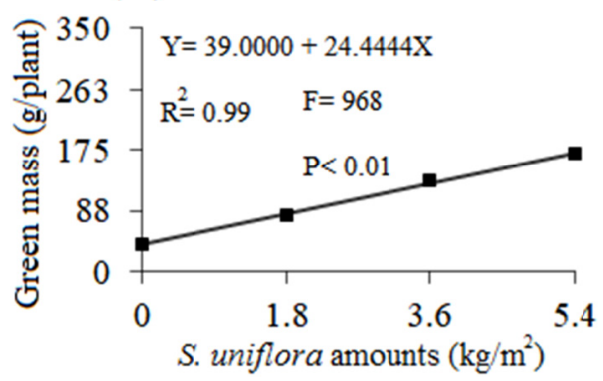

(C)

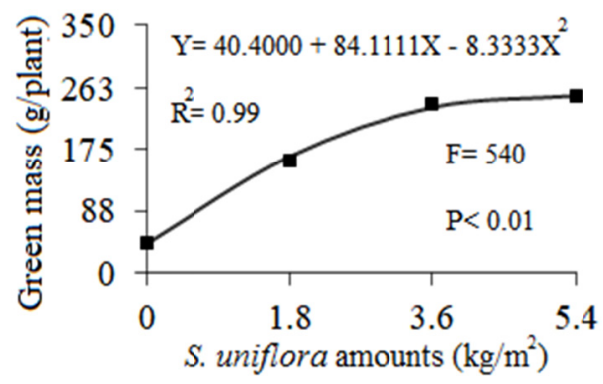

(B)

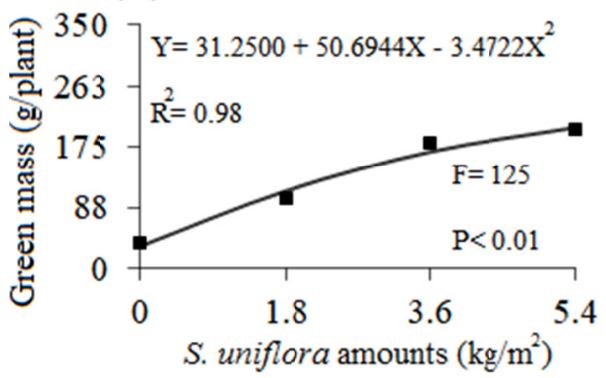

(D)

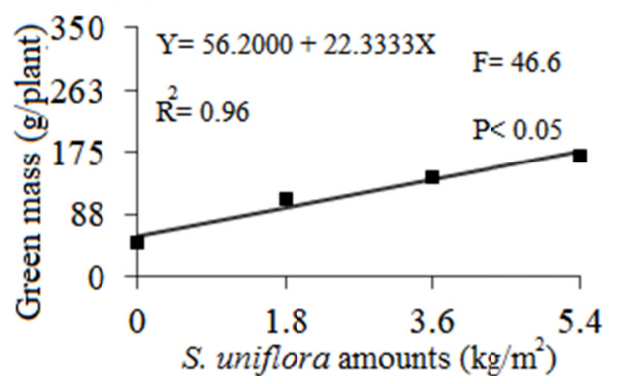

Figure 5. Green mass of lettuce, in function of partitioning of amounts of Senna uniflora in the times of incorporation into the soil of 0 day (A), 28 days (B), 56 days (C) and 84 days (D) of incorporated before transplanting 
(A)

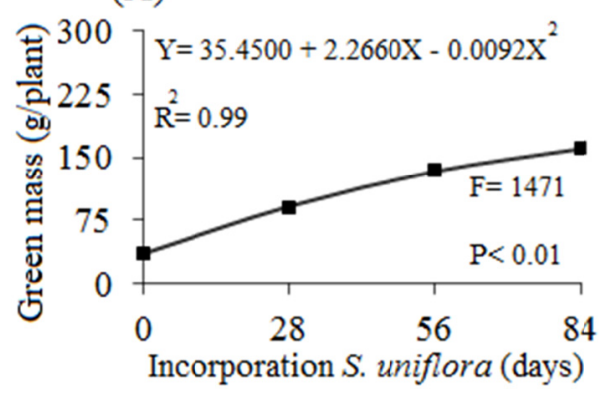

(B)

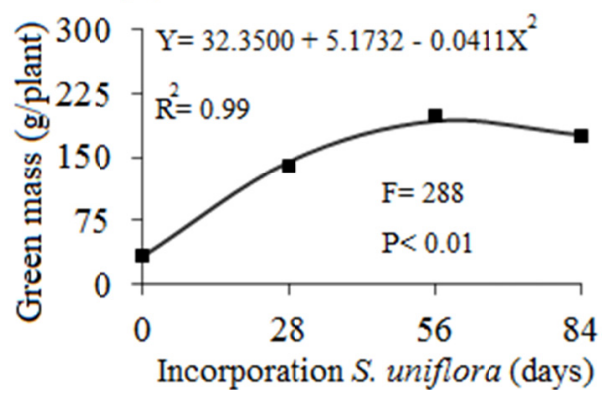

(C)

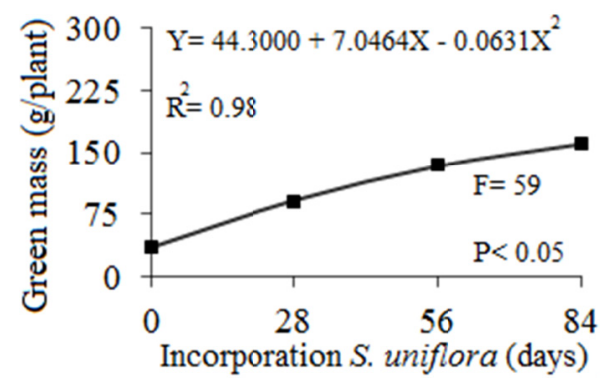

Figure 6. Green mass of lettuce, in function of partitioning of incorporation of Senna uniflora in the amounts of $1.8 \mathrm{~kg} / \mathrm{m}^{2}(\mathrm{~A}), 3.6 \mathrm{~kg} / \mathrm{m}^{2}(\mathrm{~B})$ and $5.4 \mathrm{~kg} / \mathrm{m}^{2}(\mathrm{C})$

The greatest production of green mass occurred at 56 days before transplanting, with a reduction in the time of 84 days, probably the synchronization of nutrient availability in the time of greatest requirement of the crop, was determinant for such an event. The use of $S$. uniflora becomes an economically feasible option, due to the availability of this resource in the farms, reducing the costs in the acquisition of agricultural inputs. It is worth noting that this species appears spontaneously in the rainy season every year, guaranteeing the availability of resources to the producer.

Lower values were found by Góes et al. (2011) evaluating the productive performance of lettuce at different amounts and times of decomposition of dry scarlet starglory, with production of $66 \mathrm{~g} / \mathrm{plant}$ incorporating 0.8 $\mathrm{kg} / \mathrm{m}^{2}$ of scarlet starglory. Linhares et al. (2009) studying the influence of scarlet starglory in coverage with green manuring on the agronomic performance of lettuces, with a green mass of $120 \mathrm{~g} / \mathrm{plant}$ at 42 days of incorporation. Silva et al. (2018) evaluating green manure and spatioal arrangement in the sustainabilits improvement of tettuce-beet intercrops, found fresh lettuce mass equivalent to $130 \mathrm{~g} / \mathrm{plant}$, inferior value to said research.

Higher value was obtained by Meneses et al. (2016) studying the growth and productivity of lettuce under different types of soil cover, found a fresh mass of $334 \mathrm{~g}$ when using as cover, vegetable mass. Probably, the soil cover promoted satisfactory soil conditions for the best development of the crop.

The higher production of lettuce is probably due to the improvement of soil properties, which are fundamental to the good development of plants and crop production (Costa et al., 2013; Oliveira et al., 2014).

There was an accumulation of 37.5 and $30.3 \mathrm{~g} / \mathrm{plant}$ dry mass as a function of the amount $\left(5.4 \mathrm{~kg} / \mathrm{m}^{2}\right)$ in the incorporation period of 84 days after transplanting (Figures $7 \mathrm{~A}$ and $7 \mathrm{~B}$ ). 
(A)

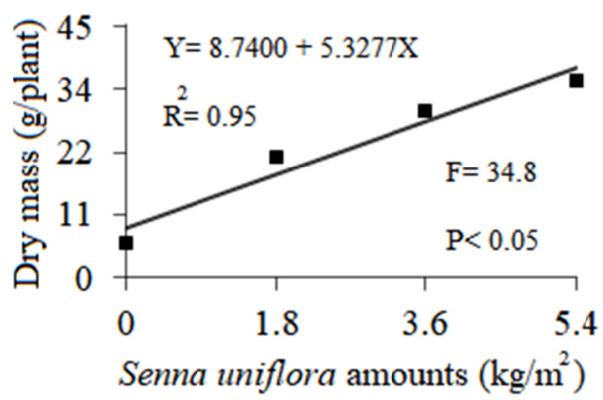

(B)

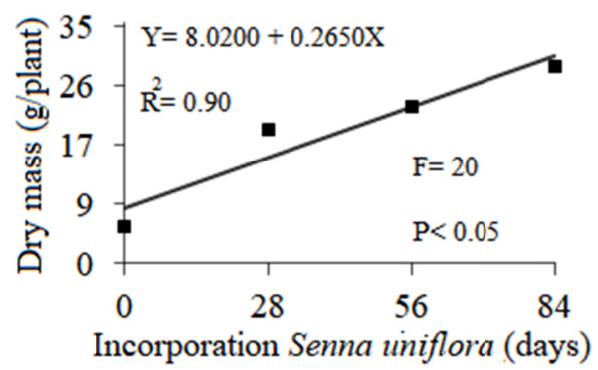

Figure 7. Dry mass of lettuce, in function of amounts (A) and times of incorporation into the soil (B) of Senna uniflora

The dry mass is a characteristic that reflects the growth of the vegetable (Taiz \& Zeiger, 2017), being of great importance in the vegetative evaluation.

Neves et al. (2018) evaluating two successive cultivation of lettuce fertilized with bovine manure in the presence and absence of mung bean, with a dry mass of $16.5 \mathrm{~g} / \mathrm{plant}$, in organic production system, which differs from said research. Oliveira et al. (2014), assessing the chemical characteristics of the soil and the production of lettuce biomass fertilized with organic compounds, found a shoot dry matter of $5.0 \mathrm{~g} / \mathrm{plant}$. This inferiority probably occurs due to the source of fertilizer used.

\section{Conclusions}

Considering the result of the research, it was observed variation of the amounts and periods of incorporation of the biomass of S. uniflora. The best agronomic efficiency was obtained with soil incorporation of $5.4 \mathrm{~kg} \mathrm{~m}^{-2}$ in the incorporation period of 56 days after transplanting, with phytomass production of $235.2 \mathrm{~g} /$ plant.

\section{References}

Altieri, M. (2012). Agroecologia: Bases cientificas para uma agricultura sustentável (p. 592). Guaíba: Agropecuária.

EMBRAPA (Empresa Brasileira de Pesquisa Agropecuária). (2018). Sistema brasileiro de classificação de solos (5th ed., p. 590). Brasília: Embrapa.

Bezerra Neto, F., Góes, S. B., Sá, J. R., Linhares, P. C. F., Góes, G. B., \& Moreira, J. N. (2011). Desempenho agronômico da alface em diferentes quantidades e tempos de decomposição de jitirana verde. Revista Brasileira de Ciências Agrárias, 6, 236-242. https://doi.org/10.5039/agraria.v6i2a977

Costa, E. M., Silva, H. F., \& Ribeiro, P. R. A. (2013). Matéria orgânica do solo e seu papel na manutenção e produtividade dos sistemas agrícolas. Enciclopédia Biosfera, 9, 1842-1860.

Filgueira, F. A. R. (2012). Novo manual de olericultura: agrotecnologia moderna na produção e comercialização de hortaliças (p. 421). Viçosa: UFV.

Góes, S. B., Bezerra Neto, F., Góes, G. B., \& Moreira, J. N. (2011). Productive performance of lettuce at different amounts and times of decomposition of dry scarlet starglory. Revista Ciência Agronômica, 42, 1036-1042. https://doi.org/10.1590/S1806-66902011000400028

Kottek, M., Grieser, J., Rudolf, B., \& Rubel, F. (2006). Mapa mundial da classificação climática de Köppen-Geiger atualizada. Meteorologische Zeitschrift, 15, 259-263. https://doi.org/10.1127/0941-2948/2006/0130

Kronka, S. N., \& Banzato, D. A. (1995). Estat, system for statistical analysis 2 (3rd ed., p. 243). Jaboticabal: FUNEP.

Linhares, P. C. F., Assis, J. P., Sousa, R. P., Sá, J. R., Pereira, M. F. S., Ramalho, W. B., .. Pereira, K. L. V. (2018). Optimized amount of hairy woodrose (Merremia aegyptia L.) in the productivity of coriander cultivars. Bulgarian Journal of Agricultural Science, 24, 654-659.

Linhares, P. C. F., Maracajá, P. B., Pereira, M. F. S., Assis, J. P., \& Sousa, R. P. (2014). Roostertree (Calotropis procera) under different amounts and periods of incorporation on yield of coriander. Revista Verde de Agroecologia e Desenvolvimento Sustentável, 9, 07-12. 
Linhares, P. C. F. (2013). Green manure as soil conditioner. Revista Campo e Negócios, 127, 22-23.

Linhares, P.C.F., Pereira, M.F.S., Assis, J.P., and Bezerra, A.K.H. 2012. Quantidades e tempos de decomposição da jitirana no desempenho agronômico do coentro. Ciência Rural, 42, 243-248. https://doi.org/10.1590/ S0103-84782012000200010

Linhares, P. C. F., Pereira, M. F. S., Almeida, S. M. S., Paz, A. E. S., \& Paiva, A. C. C. (2011). Efeito residual do mata-pasto (Senna uniflora) no desempenho produtivo do rabanete. Revista Verde de Agroecologia e Desenvolvimento Sustentável, 6, 168-173.

Linhares, P. C. F., Oliveira, R. M., Pereira, M. F. S., Silva, M. L., \& Fernandes, P. L. O. (2010). Adubação verde em diferentes proporções de jitirana com mata-pasto incorporado ao solo no coentro. Revista Verde de Agroecologia e Desenvolvimento Sustentável, 5, 91-95.

Linhares, P. C. F. (2009a). Vegetação espontânea como adubo verde no desempenho agroeconômico de hortaliças folhosas (109f. Tese, Doutorado em Fitotecnia (Área de Concentração em Agricultura Tropical), Universidade Federal Rural do Semi-Árido, Mossoró, Brazil).

Linhares, P. C. F., Silva, M. L., Borgonha, W., Maracajá, P. B., \& Madalena, J. A. S. (2009b). Velocidade de decomposição da flor-de-seda no desempenho agronômico da rúcula cv. cultivada. Revista Verde de Agroecologia e Desenvolvimento Sustentável, 4, 46-50.

Meneses, N. B., Moreira, M. A., Souza, I. M., \& Bianchini, F. G. (2016). Crescimento e produtividade de alface sob diferentes tipos de cobertura do solo. Revista Agro@mbiental On-line, 10, 123-129. https://doi.org/ 10.18227/1982-8470ragro.v10i2.3009

Neves, A. P. M., Linhares, P. C. F., Souza, R. P., Assis, J. S., Neves, A. M., Cunha, L. M. M., ... Alves, L. S. (2018). Successive crops of lettuce fertilized with bovine manure in the presence and absence of mung bean. International Journal of Development Research, 08, 19754-19760.

Novais, R. F. (2007). Fertilidade do solo. In E. J. Meurer (Ed.), Fatores que influenciam o crescimento e o desenvolvimento das plantas (pp. 65-90). Viçosa: SBCS.

Oliveira, L. B., Accioly, A. M. A., Santos, C. L. R., Flores, R. A., \& Barbosa, F. S. (2014). Características químicas do solo e produção de biomassa de alface adubada com compostos orgânicos. Revista Brasileira de Engenharia Agrícola e Ambiental, 18, 157-164. https://doi.org/10.1590/S1415-43662014000200005

Oliveira, E. Q., Souza, R. J., Cruz, M. C. M., Marques, V. B., \& França, A. C. (2010). Produtividade de alface e rúcula, em sistema consorciado, sob adubação orgânica e mineral. Horticultura Brasileira, 28, 36-40. https://doi.org/10.1590/S0102-05362010000100007

Rêgo, L. G. S., Martins, C. M., Silva, E. F., Silva, J. J. A., \& Lima, R. N. S. (2016). Pedogenesis and classification of soils of an experimental farm in Mossoró, Rio Grande do Norte, Brazil. Revista Caatinga, 29, 1036-1042. https://doi.org/10.1590/1983-21252016v29n430rc

Santi, A., Scaramuzza, W. L. M. P., Neuhaus, A., Dallacort, R., Krause, W., \& Tieppo, R. C. (2013). Desempenho agronômico de alface americana fertilizada com torta de filtro em ambiente protegido. Horticultura Brasileira, 31, 338-343. https://doi.org/10.1590/S0102-05362013000200027

Systat Software Inc. (2002). Table curve $2 D$ and $3 D$. San Jose, CA: MMIV Systat Software Inc.

Taiz, L., \& Zeiger, E. (2017). Plant Physiology (3rd ed., p. 954). Porto Alegre: Artmed.

\section{Copyrights}

Copyright for this article is retained by the author(s), with first publication rights granted to the journal.

This is an open-access article distributed under the terms and conditions of the Creative Commons Attribution license (http://creativecommons.org/licenses/by/4.0/). 